\title{
The Religion of Festival
}

\section{(Case Study on the Celebration of The Prophet's Birthday in East Lombok)}

\author{
Abdurrohman, S. Nurun \\ Study Program of Sociology Education Hamzanwadi College of Teacher Training and Education \\ Selong, East Lombok
}

\begin{abstract}
Every religion has its own tradition of religious celebration as a ritual ceremony to remember a historical event or to worship God as an expresion of gratitude. Indonesian people is characterized by multi religious life which is rich by ceremony and religious festival. Lombok which is well known as "a thousand of mosque island" is a typical homogenous society belong to Sasak ethnic and the piety Islam followers. This could be found by the enthusiasm and religious spirit of the society in the celebration of Mawleed or the Mohammad prophet's birthday by organizing various contests and festivals. In this case, East Lombok society celebrate the mawleed not only for worship as a token of love and respect for Rasulullah peace be upon him but also for entertainment . Finally, the festivals which used to religious and sacred turned into profane activities. The most important here is teh festival instead of the religious values. This phenomenon was called as "festival reliogion" not "religious festival".
\end{abstract}

Key Words : Festival, Religion, Prophet's Birthday

\section{INTRODUCTION}

Komaruddin Hidayat stated that "there are no religions without ceremony and festivalsl". Almost all main religions in the world have their own ceremony and religious festivals. Indonesian people who are characterized by multireligious ethnics and strong believers are rich of ceremony and sacred festivals. Islam, Hindu, Christian, Buddhist, Konghucu and other religious sects celebrate their traditions related to religion sacred days. Christmas day is celebrated cheerfully by adorning christmas tree at home of the Christians. Imlek or Chinese New Year is also higlighted with lion dance festival by the Chinese descent. Vesak is claimed as the most prominent sacred day by the Buddhist is highlighted by decorating temples. Furthermore, Hindu is the richest religion with ceremonies and religious festivals although they are held locally in Bali. Regarding that Indonesian society are majority moslems, so the celebration of Islamic sacred days are held lively in this country. Say for example the celebration of Iedl al Fitr, Iedl Adha, the $1^{\text {st }}$ Muharrum, Islamic Hijreea New Year, The prophet birthday and so forth. The sacred days are always celebarted lively by the moslems by holding ceremony and religious festival. Through the celebration and festivals, the spirit and religious tradition are perpetuated and inheritaged from one generation down to the next generation. Those phenomena also occur in Lombok which is well known as the "island of thousand mosques". East Lombok society who belongs to "Sasak" ethnic are popular as strong islamic believers are rich of ceremony and religious festival such as in the celebration of prophet Mohammad birthday. The people of East Lombok celebrate the birth of prophet Mohammad in unique way which is different from other islamic sacred days. In the celebration of prophet Mohammad's birthday, people enliven by organizing contests and festivals. However, whether it is realized or not, as the time passed by, the celebration of prophet mohammad's birthday in East Lombok has changed a lot, its culture nuisance was stronger and further than the religious messages. Based on the religious phemona above, the presenet researcher is interested in conducting a research.

\section{MAWLEED FESTIVAL}

East Lombok is an area in Lombok Island and administratively includes in a regency lies in West Nusa Tenggara province. East Lombok society who belong to Sasak ethnic is typically homogenous either culturally, East Lombok society who belong to "Sasak" ethnic is typically homogenous either cultural, social, or religious. Most of Sasak people are strong and piety Islamic followers. Their religiousity is proved by a high number of mosques with glorious and beautiful building architectures which can be found in every areas of this island. Therefore, the island is popular with "the island of a thousand mosque"..

Furthermore, as the majority islamic believers, their loyalty can be found by the people's enthusiasm to celebrate islamic sacred days like 
Eidl al Fitr, Eidl Adha, Hijreea New Year of the $1^{\text {st }}$ muharrum, the prophet Mohammad's birthday (p.b.uh) or mawleed and so on. To celebrate the prophet's birthday, people welcome it enthusiastically by organizing various contests and festivals. There are islamic contests such as contest of memorizing short surahs, adhan and qashidaa singing, some others hold cultural contests like hitting earthenware, sack race, climbing areca nut tree and so forth. Generally, prophet's birthday celebrations in any villages in East Lombok tend to be similar, in the case that people celebrate it by organizing various contests both islamic and cultural, but every corner has its own characteristics. As the time passes by, the contests and festivals in the prophet's birthday changed alot which can be found in any village. For example, in Rempung where the inhabitants are enthusiast in celebrating the prophet's birthday. In this village, the cultural touch of contests andfetsival in prophet's birthday or mawleed is stronger than the religious values. Adnan stated as follows:

"These years, there are a lot of contest hold in Rempung to celebrate the prophet Mohammad's birthday tend to be modernized like music carnaval, futsal match and dance for kids and teenagers. "

\section{As an additional Munawar also said}

“ These days, some contests hold by the committee of Islamic sacred day lack of religious values, such as dance contests, singing, music carnival, futsal in which the contests have nothing to do with religion even cause problems for the society like quarrel among the players in futsal match, and the riot during music carnival because the organizer usually invite the youth to consume liquor"

In the celebration of prophet Mohammad;s birthday, there is a function which is waited most by Rempung people, that is "Kembuli" or carnival. "Kembuli" has been the unique characteristics of Rempung people in celebrating the prophet's birthday as well as the the culmination of sequence activities to the prophet's birthday celebration. Nowadays, "Kembuli" festival has changed and tend to contain cultural content instead of religious values such as decorating motorcycle, car or cattle, even the "Kembuli" festival is also followed by rock or dangdut music and drum as well. The following statement is also a confession from Usma Sarbini.

"Kembuli carnival is not interesting to see now because it is so common. There are some attendants who decorate motorcycle, some others decorate car then they place tape recorder and video compact disc then they will play loud rock music instead of qaseedah, in other word Kembuli is adorned with money since the jury will score the money"
Based on illustration above, it can be explained that contests and festivals of the prophet Mohammad's birthday merely show entertainment side, far from religious values as what happens in Rempung village, so it is in contrast with the noble purpose to celebrate the birthday of prophet Mohammad which should be done by having shalawat and dhikr. Even, kembuli" festival presents cultural values more than religious messages. Furthermore, "kembuli fetsival" also causes certain problems for the society such as riot and liquor consumption among the youth .

The similar phenomena also occurs in any village at Pohgading distric. From every corner of village, the preparation of the prophet's birthday can be found since seven days before the highlight activity. People's enthusiasm was so high to participate in the celebration of prophet Mohammad's birthday by following various contests held by the committee in each village. Even in the village of Gegurun, there is a kind of contest which is waited most by its inhabitants, that is dangdut ball match. This match becomes the characteristics of Gegurun village in the celebration of prophet Mohammad's birthday. In Ketangga village, Suela district, there is a dangdut singing which is so splendid and entertaining for the society.

Finally, based on the researcher's observation, in every Mawleed month, the people of Esat Lombok are very enthusiast to celebrate the birthday of prophet Mohammad by holding various contests and festivals, in which the types of contests and festivals among one village and the others are similar, namely religious contests and cultural contest as the cases occur in villages mentioned above.

\section{THE RELIGION OF FESTIVAL}

Based on the research result above, it could be explained that East Lombok people are very enthusiast to celebrate the prophet Mohammad's birthday. This is an expression of society's religiousity which has become a tradition and inherited from one generation down to the next generation. The birthday of prophet Mohammad's celebration is one of religious festivals which is celebrated lively and cheerfully as well as an entertainment in Mawleed month every year. In this context, the people celebrate the prophet's birthday do not only for worship purpose as the token of love to Rasulullah p.b.u.h but also for entertainment. This could be found out on the people's enthusiasm by organizing various and religious festivals, both islamic contests and cultural contests. However, contests and festivals which should be religious changed into cultural festivals which are far from the religious values, in which sacred and profane influence and mix each other. This religious festival 
according to Komaruddin Hidayat (2010) is called "Festival religion". " not religious festival.

Religious causes cultural festival and at last festivals which used to religious changed into profane festivals.

Furthermore, sosiologically the celebration of prophet Mohammad's birthday could unite among people (in this case religion community). Through the celebration, there are togetherness, and unity or according to Durkheim, celebration may strenghten social solidarity. This could be seen when the society elements are united and do mutual work from paying fee, participatiing in contests and highlighting the mawleed celebration. According to Durkheim, unity was created from ritual and religion, thus making religion as mutual affair.

\section{CONCLUSION}

East Lombok people constitute homogenous society typically either cultural, social or religion. In the case of religious matters, the majority people are piety believers of Islam and hold high spirit or religious values. The piety in religion is shown by the enthusiasm in celebrating the prophet of Mohammad's birthday. Every Mawleed month, the inhabitants of East Lombok from all villages welcome the celebration by organizing various contests and festivals. There are islamic contests such as memorizing short surahs of the holy qur'an, adhan, religious brain battle, qasheeda singing, and there are cultural contests such as hitting earthenware, sack race, climbing betel tree and so on. These religious festivals are preserved and inherited from one generation down to other generation. Every village has its own characteristics and uniqueness in celebrating the prophet's birthday. In this context, people do celebrate the prophet's birthday not only as a worship and token of love for Rasulullah p.b.u.h (peace be upon him) but also as a form of entertainment. Finally, contests and festivals which should be religious changed into cultural festival which is far from religious values. In that point, values and religious belief mix with cultural aspects, in which sacred and profane affect each other. Religious values and cultural mix each other. This phenomena is called "festival religion" not "religious festival".

\section{REFERENCES}

[1] [1] Arifin, Syamsul, 2009, Studi Agama Perspektif Sosiologis Dan Isu-isu Kontemporer, Malang, UMM Press

[2] [2] Agus, Bustanuddin, Agama dan fenomena sosial Buku ajar Sosiologi Agama, Jakarta UI Press

[3] [3] Abdullah, Amin,2011, Studi Agama Normativitas atau Historisitas?, Yogyakarta, Pustaka Pelajar

[4] [4] Hidayat, Komaruddin, Festival Agama, Agama Festival, SKH Kompas, 6/12/2010

[5] [5] Hidayat, Komaruddin, 2012, Agama Punya Seribu Nyawa, Jakarta, Noura Book

[6] [6] Hanani, Silfia,2012, Menggali Interelasi Sosiologi dan Agama, Bandung, Humaniora

[7] [7] Robert, Bogdan, dan Steven J. Taylor,1992, Pengantar Metode Penelitian Kualitatif, Alih Bahasa: Arief Furchan, Surabaya: Usaha Nasional. 